\title{
Conflitos entre religiosos numa missão católica no interior de Goiás na década de 1950: Ressentimentos de Remígio Corazza em seu relato autobiográfico
}

\author{
Conflicts among religious people in a Catholic mission in the countryside of Goiás state \\ in the I950s: Resentment of Remigio Corazza in his autobiographical account
}

\section{Raylinn Barros da Silva*}

Resumo: O objetivo deste estudo foi desvelar os conflitos que ocorreram entre religiosos no interior da missão católica orionita no antigo extremo norte de Goiás na metade do século XX. Tem-se como hipótese a possibilidade de que esses conflitos podem ter influenciado em algum momento no desenrolar da missão. Este estudo é resultado de uma pesquisa bibliográfica e a fonte utilizada foi o relato de memória - livro autobiográfico Silêncio Prudente - de um desses religiosos: Remígio Corazza. A metodologia partiu de uma análise da obra tendo como referenciais estudos sobre autobiografias, memória e ressentimentos. Uma justificativa para este estudo é a necessidade de historicizar essa fonte que pode contribuir para compreensão da missão orionita na região por outro viés: o dos conflitos internos entre alguns de seus membros.

Palavras-Chaves: Goiás; Orionitas; Conflitos.

Abstract: The aim of this study was to uncover the conflicts that occurred between religious people inside of the Orion Catholic mission in the old extreme north of Goias state in the middle of the 2oth century. One hypothesis is the possibility that these conflicts may have influenced at some point in the development of the mission. This study is the result of a bibliographical research and the source used was the memory report - autobiographical book Silêncio Prudente - of one of those religious members: Remígio Corazza. The methodology was based on an analysis of the work having as reference studies on autobiographies, memory and resentments. A justification for this study is the need to historicize this source that can contribute to the understanding of the Orion mission in the region by another bias: the internal conflicts among some of its members.

Keywords: Goiás; Orionites; Conflicts.

\footnotetext{
* Doutorando e Mestre em História pelo Programa de Pós-Graduação da Universidade Federal de Goiás. Especialista e Licenciado em História pela Universidade Federal do Tocantins. Autor do livro: Pedro Milagroso, o mendigo que virou santo, Editora Kelps, 2013.
} 


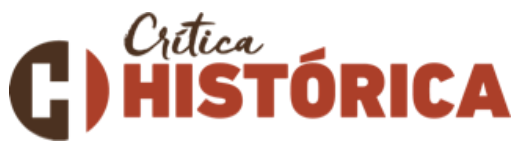

\section{Introdução}

Este estudo pretendeu desvelar os conflitos que se deram entre alguns religiosos no contexto da missão católica orionita na região do antigo extremo norte goiano, região onde atualmente é o norte tocantinense, na metade do século XX. A partir dos relatos autobiográficos do missionário Remígio Corazza e, sobretudo, seus ressentimentos com relação a outro orionita, Giovani Pattarello, tem-se como hipótese que esses conflitos internos durante a missão podem ter influenciado em algum momento o desenrolar da mesma no contexto temporal e espacial abordado.

A principal justificativa para esta investigação consistiu na necessidade que se impõe de historicizar esses relatos de Corazza que se acredita, pode contribuir para a compreensão da missão orionita na região, mas por outro viés: o de alguns conflitos internos entre seus membros. Mas quais as fontes foram utilizadas neste estudo? Quais os desafios se impuseram à realização desta investigação? Os materiais utilizados na feitura deste estudo são objetos de observação a seguir.

\section{A documentação e os desafios de seu uso}

A documentação utilizada neste estudo consistiu nos relatos autobiográficos de Remígio Corazza, missionário orionita que participou da missão em Goiás desde o primeiro ano. Corazza escreveu duas obras de memória, uma em particular tem relação com os objetivos deste estudo, o livro Silêncio Prudente. Publicado no início dos anos 2000, nele, Corazza ao que parece, resolveu relatar em um tipo de escrita carregada de ressentimento, alguns momentos com riqueza de detalhes, os bastidores da missão em Goiás, sobretudo, segundo ele, as "manobras" desencadeadas por quem ele aponta como o responsável por perseguições e disputas internas na missão, o também sacerdote orionita Giovanni Pattarello.

Peter Gay, historiador alemão, estudioso da chamada psico-história, ao refletir sobre a relação entre ressentimento e sofrimento, infere que esses sentimentos quando submetidos ao espaço da religião, torna-se um tema explosivo, pois que, na maioria das vezes, quem retém na memória determinadas experiências, as relata como acontecimentos extraordinários e, na maioria das vezes, como vivências traumáticas ou mesmo ressentimentos (GAY, 1999, pp. 337-376). Ao que parece, o livro de memória de Corazza teve esse aspecto: lugar explosivo que fez brotar seus ressentimentos, sofrimentos, suas vivências traumáticas fruto de sua conturbada relação com Pattarello. 


\section{C) HitceátóRICA}

Quanto a esses registros de memória autobiográficos de Corazza, deve-se inferir que algumas limitações foram impostas na investigação e consequente feitura deste estudo. $\mathrm{O}$ primeiro desafio e que impôs uma limitação imediata, é a ausência de referências precisas sobre as datas em que ocorreram cada conflito, cada perseguição, segundo Corazza, por parte de Pattarello. Portanto, Corazza traz em seus relatos autobiográficos riquezas de detalhes, mas não informa o momento exato em que eles se deram. Por esse motivo, não foi possível organizar este estudo dividido em períodos históricos, a única referência precisa é que ocorreram na década de 1950 e início da década seguinte, ou seja, nos primeiros dez anos da missão orionita em Goiás.

Por serem relatos de memória, a voz de um só religioso: Corazza, impôs uma versão única para a narrativa e a consequente análise. Mas desde o princípio, ao constatar-se a ausência de outras versões para os registros de memória de Corazza, como por exemplo, a versão de Pattarello ou mesmo da congregação orionita, fez com que trabalhássemos exclusivamente com os relatos de Corazza e que, por esse motivo, aumentou o desafio de historicizar um documento de "mão única", mas que, acredita-se não diminuiu a capacidade analítica dessa investigação.

Mas qual congregação pertencem esses missionários? Quem é o fundador desse grupo religioso? Como essa congregação se dispersou pelo mundo? Quais foram os primeiros missionários orionitas designados para Goiás na época? Como eles encontraram a região? Em qual projeto de igreja em nível de país a missão orionita em Goiás se encaixa? Essas são as questões que orientam a reflexão a seguir.

\section{Os missionários orionitas: quem são?}

Os missionários orionitas pertencem à congregação denominada “Pequena Obra da Divina Providência". São chamados "Filhos da Divina Providência" ou simplesmente “orionitas”. Essa congregação religiosa pertence à Igreja Católica, fundada pelo sacerdote italiano Dom Luís Orione. Os missionários orionitas são padres e religiosos católicos que no século XX se dispersaram pelo mundo, mais precisamente a partir do pós-primeira guerra, imbuídos por um ideário de vida e de serviço à Igreja Católica e de assistência aos pobres, esses preceitos eram os norteadores da vida de Dom Luís Orione ${ }^{\mathrm{I}}$ (PATTARELLO, 1985, p. 9).

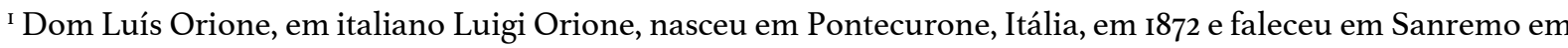
1940. Ao entrar para a vida religiosa, pertenceu à congregação dos padres salesianos, ordem religiosa fundada pelo sacerdote Dom Bosco, de quem Dom Orione desfrutava de amizade. Dom Orione viveu a sua vida praticando a caridade. Fundou em 1903 na cidade de Tortona a congregação Pequena Obra da Divina Providência, formada por padres, freiras e leigos consagrados. Presente em quase todo o mundo, é mantida
} 


\section{C) HitistóríRICA}

Sobre essa congregação religiosa católica, é considerada uma das mais novas na estrutura da Igreja Católica. Pouquíssimos trabalhos acadêmicos abordam essa congregação, sobre ela, sabe-se que tem como campo de atuação a assistência aos pobres e, sobretudo, a prática da caridade, por meio do oferecimento de educação, saúde e cultura, além claro, da assistência religiosa em seus templos - igrejas - ao redor do mundo. O chamado carisma orionita tem como assento essa premissa: a caridade. Especificamente sobre a presença dessa congregação orionita no espaço do antigo norte goiano, o geógrafo Jean Carlos Rodrigues observa que:

A chegada, instalação e difusão da Congregação da Pequena Obra da "Divina Providência" no norte do Estado de Goiás na década de 1950 foi capaz tanto de imprimir formas religiosas na paisagem (construção de igrejas, escolas e hospitais) como foi também importante para constituir uma identidade religiosa cristã, de vertente Católica Romana, de carisma orionita nesta região (RODRIGUES, 20I6. p. 52).

Conforme refletiu Rodrigues, a presença da congregação orionita mudou a paisagem da região, por intermédio de suas construções - igrejas, escolas e hospitais - e que, segundo ele, essa presença contribuiu para a constituição, a partir dos orionitas, para uma identidade cristã de carisma orionita, ou seja, o carisma da congregação para ele está ligado a essas esferas: igreja, educação e saúde, dimensões em que a congregação, a nosso ver, atua no âmbito da caridade.

Essa congregação e seus membros, os orionitas, estão presentes em quase todos os continentes, com uma atuação mais destacada na América Latina e Europa. Sobre os missionários que foram designados à região do antigo extremo norte goiano, atual norte tocantinense, em fevereiro de 1952, não foram muitos, mas os que foram para região se transformaram nos protagonistas do processo de institucionalização da Igreja Católica que aconteceu no contexto ${ }^{2}$.

Eles se estabeleceram no território goiano no início da década de 1950 e até os dias atuais encontram-se no mesmo. Com a divisão de Goiás em I988 dando origem ao Tocantins,

com doações de católicos. A partir da metade do século XX seus seguidores se espalharam pelo mundo, inclusive o Brasil. Seus religiosos são chamados "Filhos da Divina Providência". Foi beatificado em I98o e canonizado em 2004, as duas cerimônias presididas pelo então papa João Paulo II. Para mais informações sobre a vida e obra de Dom Orione, consultar: PATTARELLO, Giovani. Perfil de Dom Orione. São Paulo: S/Editora, 1985.

${ }^{2} \mathrm{O}$ processo de institucionalização da Igreja Católica na região não é tema de reflexão neste estudo. Para mais informações sobre o tema, consultar: SILVA, Raylinn Barros da. O Catolicismo Orionita no Antigo Extremo Norte Goiano nos Relatos de Memória dos "Filhos da Divina Providência" 1952-1980. Dissertação de Mestrado. Programa de Pós-Graduação em História. Goiânia: UFG, 2017. 
os missionários orionitas ampliaram a missão, na atualidade, possuem creches, escolas de ensino fundamental e médio, uma faculdade, casas de acolhida, centros de convivência de idosos, centenas de igrejas e um hospital, considerado o maior e mais moderno do norte tocantinense. Não se considera mais que os orionitas estão em missão pela região como estiveram na década de 1950 e I960. Muito embora eles ainda se considerem missionários, acredita-se que o trabalho da congregação na região encontra-se consolidado, devido ao alcance de sua atuação na região.

Os primeiros missionários orionitas que foram designados para a região foram: Quinto Tonini, Pacífico Mecozzi, Teresinha Foli e Remígio Corazza. Giovanni Pattarello não atuou na região como missionário, mas sua participação nos bastidores da missão o transformou, segundo Corazza, em personagem central dos conflitos que ocorreram no interior da missão.

Sobre Tonini, nos primeiros anos da missão orionita na região, a partir de 1952, atuou como liderança quase incontestável no interior da missão. Ao chegar na região com seus conhecimentos de enfermagem, atuou como uma espécie de padre-médico, tratando e curando os doentes. Para onde foi deslocado, construiu igrejas, abriu escolas e postos de saúde. Logo após sua chegada na região, foi sendo reconhecido por seu trabalho e habilidade, o que lhe assegurou a condição de líder entre os orionitas na região³.

Sobre Mecozzi, era considerado um dos principais missionários alinhados à Tonini, após a renúncia desse último, foi designado como vigário capitular da prelazia de Tocantinópolis de 1959 a 1960. Acredita-se que Mecozzi não teria ficado por mais tempo no cargo em virtude dos superiores da Igreja em Roma buscar logo uma solução para os problemas da igreja na região, ou ainda, a nomeação de um Bispo colocaria fim às disputas internas por poder dentro da igreja na região. 4

Sobre Teresinha Foli, era freira orionita, foi a única do grupo dos aliados de Tonini que não era estrangeira, era da região da missão, a pequena cidade de Filadélfia, um dos principais centros de atuação dos missionários. Também não pertenceu ao primeiro grupo

\footnotetext{
3 Tonini foi o primeiro administrador apostólico da prelazia de Tocantinópolis de 1956 até sua renúncia em 1959. Assim como Corazza, Tonini deixou sua obra autobiográfica, o livro Entre Diamantes e Cristais, produzido pela Editora Expressão, Fortaleza, 1996. Essa obra autobiográfica de Tonini não tem prefaciador e segundo o autor não foi nem autorizada pela congregação muito menos recebeu da mesma congregação apoio financeiro para ser publicada.

${ }_{4}^{4}$ Mecozzi pertencia ao grupo de Tonini, o fato dele tê-lo substituído demonstra, ao que parece, a influência que Tonini ainda possuía na região. Mecozzi, nessa trama, ocupa o lugar de aliado de Tonini, nas narrativas de memória de Corazza, ele considera Mecozzi como homem de confiança de Tonini e aliado do mesmo à época. Mecozzi, do grupo dos primeiros missionários que atuaram na região, foi o único que não deixou livro autobiográfico produzido.
} 


\section{C) HitistóñICA}

dos que atuaram na região. Tonini, ao chegar em Filadélfia em 1952, hospedou-se na casa dos pais dela, à época muito jovem, logo entrou para o seminário e escolheu pertencer à Congregação das Pequenas Irmãs Missionárias da Caridade, braço feminino da congregação orionita (FOLI, 2003, p.19). ${ }^{5}$

Sobre Corazza, no grupo muito próximo de Tonini, foi o mais severo crítico de Pattarello. Durante este estudo, era o único dos missionários ainda vivo. Assim como Pattarello, também conheceu e conviveu com Dom Orione. Foi ordenado sacerdote católico em 1952, doze anos após a morte de Dom Orione e no mesmo ano ingressou na missão orionita na região. No ano seguinte, 1953 , foi enviado para Tocantinópolis como missionário. ${ }^{6}$ Já sobre Pattarello, quando da missão orionita em Goiás, era o superior geral dos missionários no Brasil, maior cargo da congregação no país. ${ }^{7}$

Estabelecendo uma relação entre os orionitas e a história da região em que eles atuaram, como estava o norte goiano antes dos orionitas chegarem à região? Do ponto de vista da religião católica, o antigo extremo norte goiano - com exceção de Boa Vista, atual Tocantinópolis, já possuía uma paróquia católica - era "assistida" do ponto de vista religioso, vez ou outra, quando da passagem de missões religiosas. Primeiro os capuchinhos no final do século XIX e, no início do XX, os dominicanos.

Sobre esses últimos, a historiadora Vera Caixeta informa que nas primeiras décadas do século XX “Os frades ainda são responsáveis pela Diocese de Porto Nacional e pela Prelazia de Conceição do Araguaia. Assim, os frades já estavam plenamente estruturados no Brasil Central, com uma experiência de mais de vinte anos no interior do Brasil” (CAIXETA, 20I4, p. 89). Os primeiros registros de atuação da Igreja pela região se deveu a esses religiosos, mas uma atuação enquanto missão, não como igreja institucionalizada. A Igreja

\footnotetext{
5 Interessante observar que os registros de memória tanto de Tonini quanto de Foli levam a acreditar que eles alimentaram até os dias finais de suas vidas uma paixão que, o que se acredita, pode ter interferido no desenrolar da missão. Foli, assim como Tonini e Corazza, também deixou seu livro autobiográfico, a obra Meandros da Verdade, produzido pela Editora GM, 2003. Essa obra autobiográfica de Foli, assim como a de Tonini e Corazza, não tem prefaciador e segundo a autora não foi nem autorizada pela congregação muito menos recebeu da mesma congregação apoio financeiro para ser publicada.

${ }^{6}$ A partir dos relatos de memória de Corazza, é possível perceber que durante a missão, ele se tornou além de amigo de Tonini, seu "braço direito". Seu livro autobiográfico Silêncio Prudente, foi produzido pela Editora Expressão, 200o. Essa obra é a única que aborda a missão orionita pelos seus bastidores internos, ele apresenta nesse seu livro autobiográfico, o que pode ser entendido como o outro lado da missão orionita em Goiás na época. Essa obra autobiográfica de Corazza, assim como a de Tonini e de Foli, não tem prefaciador e segundo o autor não foi nem autorizada pela congregação muito menos recebeu da mesma congregação apoio financeiro para ser publicada.

7 Pattarello, assim como Tonini, Foli e Corazza, também deixou seu escrito, o livro biográfico em que ele discorreu sobre a biografia do fundador da congregação orionita, o livro Perfil de Dom Orione, produzido de forma independente, sem editora, no ano de 1985. Diferente das obras autobiográficas de Tonini, Corazza e Foli, esse livro de Corazza recebeu apoio financeiro da congregação para ser publicado.
} 


\section{C) CitsistórICA}

Católica não estava estruturada enquanto templo edificado e com celebrações costumeiras. Ou seja, antes dos missionários orionitas, a região de tempos em tempos recebia a visita de missões católicas de passagem pelo lugar.

Imagem I: Mapa da missão orionita nas duas primeiras décadas de atuação na região, abrangência por cidades.

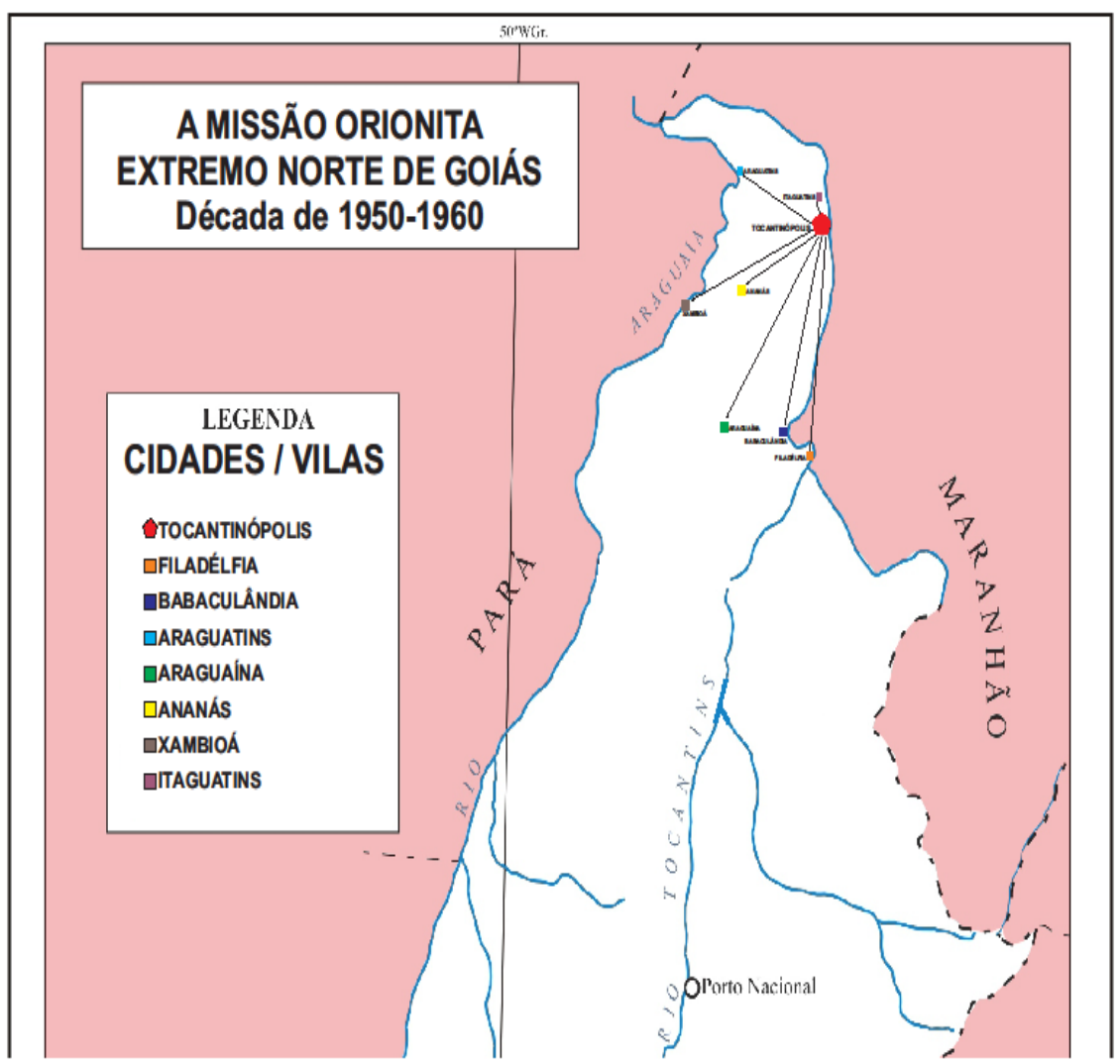

Fonte: Imagem produzida a partir da leitura das fontes autobiográficas dos orionitas

Já estabelecendo uma relação entre os orionitas e a história do Brasil no período, sobretudo a história da Igreja Católica em nível nacional no contexto abordado neste estudo, pode-se inferir que a atuação dos missionários orionitas em Goiás estava inserida no contexto da chamada neocristandade. Nesse sentido, qual projeto, em nível de Brasil estava sendo colocado em prática pela instituição católica? Para refletir sobre essa problemática, vale observar o apontamento esboçado pelo historiador Riolando Azzi, um dos mais destacados especialistas no estudo do catolicismo no país. De acordo com ele, o projeto católico buscava:

Valorizar o papel da religião na manutenção e na coesão da ordem social. Os prelados brasileiros vão ainda mais além em suas reivindicações: desejam que, de fato, a fé católica possa ser o princípio inspirador da ação 


\section{C) CitsistórICA}

política dos governantes e da própria organização jurídica e social da sociedade. Querem que o Brasil se torne efetivamente um Estado Cristão, ou seja, uma nova cristandade (AZZI, I994, p. 60).

Segundo Azzi, o projeto do catolicismo para o Brasil naquele contexto histórico do início do século XX, um projeto denominado de neocristandade e que ainda mostrava força nos anos 1950 em diante com os missionários orionitas no antigo extremo norte goiano. Como se deram as articulações entre os orionitas? Quais conflitos ocorreram? Quem esteve por trás dos mesmos? A missão orionita vista sob a ótica de Corazza, um dos principais missionários que atuaram na missão, é objeto das reflexões a seguir.

\section{Bastidores da missão orionita em goiás: conflitos internos vistos a partir dos ressentimentos de Remigio Corazza}

Como sabe-se, a análise dos bastidores da missão orionita se deu a partir dos registros de memória do missionário Corazza que, ao relatar a sua vida no contexto da missão orionita em Goiás, terminou por legar apontamentos que permitem ver a mesma missão por outro viés: dos seus bastidores. Para o trato com essas memórias, utilizou-se os estudos de Ecléa Bosi, em que ela buscou analisar os discursos de idosos a partir da reconstrução das suas memórias, além da inserção desses mesmos na sociedade. Segundo Ecléa Bosi, "A narração da própria vida é o testemunho de mãos eloquentes dos modos que a pessoa tem de lembrar. É a sua memória" (BOSI, 2003, p. 68). Acredita-se, portanto, que os registros de memória de Corazza é o seu testemunho, sua memória dos acontecimentos.

Nesses acontecimentos, segundo Corazza, esteve um personagem que, segundo ele, foi perseguidor e articulador de várias "tramas" que fizeram parte da missão religiosa à época. O "algoz" de alguns orionitas foi um sacerdote italiano que no contexto objeto deste estudo era o provincial da congregação orionita no Brasil: Pattarello. Segundo Corazza, ele perseguiu e tramou contra Tonini e os missionários que estavam sob sua influência, inclusive ele próprio, Corazza. Pattarello e sua trajetória de vida é pouco conhecida. Contudo, através de suas memórias, sabe- que conheceu e conviveu com Dom Orione. $\mathrm{Na}$ década de 1950 foi designado como superior dos orionitas no Brasil, cargo de provincial que exerceu por vários anos (PATTARELLO, 1985, p. II).

Sobre sua obra de memória intitulada 'Silêncio Prudente', é seu registro autobiográfico. Para o trato com essa fonte, este estudo apoiou-se nas reflexões de Maria 


\section{C) CitsisTórICA}

Lígia Leite Pereira, quando reflete que em alguns estudos autobiográficos, o narrador é quem dá o encaminhamento que melhor considera para a sua história de vida, pois, segundo ela:

Uma autobiografia consiste na narrativa da própria existência e, como salienta Maria Isaura Pereira de Queiroz (1988), nela foi o próprio narrador quem se dispôs a narrar sua vida, deu a ela o encaminhamento que melhor lhe pareceu e deteve o controle sobre os meios de registro (PEREIRA, 200o, p. II8).

Sobre o escrito, pode-se inferir, ainda, que é um registro de memória impregnado de ressentimentos por Pattarello. Por esse motivo, utilizou-se neste estudo as reflexões de Pierre Ansart. Para ele, nos estudos sobre ressentimento, é necessário observar a existência de várias formas para a manifestação do mesmo. Ansart acredita que além da ausência de afeto, outros sentimentos como revolta, além de discursos e representações podem ter relevante papel na manifestação do ressentimento (ANSART, 2004, p. I6).

Tonini foi o missionário que mais se destacou à época da missão. Acredita-se que, como evidência de que seu trabalho foi amplamente reconhecido pela Igreja, quatro anos após sua chegada em 1956, foi nomeado administrador apostólico da Igreja Católica na região. À época, acreditava-se que o cargo de administrador apostólico resultaria na conversão do mesmo em Bispo. Segundo Corazza, a partir da escolha de Tonini para o cargo, a vida desse último e Pattarello se "cruzaram" e como será possível perceber, para a "infelicidade" de Tonini. Mas por que para a infelicidade de Tonini?

Porque quando da escolha do mesmo como administrador apostólico para a região, seu nome estava em disputa interna com mais outros nomes entre os orionitas, dentre esses se destacava o próprio Pattarello ${ }^{8}$, ao que parece, pleiteava o cargo entregue à Tonini. A partir da escolha do Vaticano pelo nome de Tonini para a administração dos católicos na região, começou a rivalidade de Pattarello contra Tonini, rivalidade que durou até I959, quando da renúncia de Tonini ao cargo. A rivalidade entre os dois causou dificuldades tanto para Tonini como também para as pessoas mais próximas dele, como o próprio Corazza, além de Mecozzi e Foli.

Sobre a renúncia de Tonini do cargo de administrador apostólico, Foli registrou que dias após ela ter se dado, ela recebeu a visita do próprio Tonini que acabara de deixar a chefia da missão e estava a caminho do Uruguai. Segundo ela:

\footnotetext{
${ }^{8}$ Sobre a escolha de Tonini e o fato de Pattarello ter sido preterido no momento pelo Vaticano, ver: FOLI, Teresinha de Jesus Nóbrega. Meandros da Verdade. Fortaleza: GM Editora, 2003, p. 9.
} 


\section{C) HitsớróRICA}

Depois de deixar Tocantinópolis fui destinada para trabalhar em Siderópolis, Santa Catarina. Certa manhã a campainha tocou. Fui atender e deparei-me com o Pe. Tonini. Perguntei por amigos e parentes que eu havia deixado em Goiás. Notei que ele estava taciturno, estranho, diferente. Quando lhe pedi se podia levar uma carta minha ao papai, ele respondeu: Não vou mais voltar para o Goiás. Estou aqui de passagem para o Uruguai, meu novo campo de trabalho. Como? Está me dizendo que deixou a missão e vai deixar também o Brasil? Sim, renunciei. Pe. Tonini contou-me os motivos que o levaram àquela resolução. Não percebi nele nenhum sentimento de revolta, mas uma tristeza profunda, que procurava esconder (FOLI, 2003, pp. I2-I3).

Como registrou Foli, Tonini visitou-a logo após sua renúncia. Ela não explicita os motivos que levaram Tonini a renunciar ao cargo, preferiu ocultá-los. Uma observação atenta da narrativa de Foli, leva a acreditar que não foi uma renúncia espontânea. Se assim fosse, Foli não teria registrado em suas memórias a expressão "não percebi nele nenhum sentimento de revolta". Se Tonini tivesse renunciado por motivos pessoais, ou seja, uma decisão sem pressão, por que Foli haveria de fazer a observação de que não percebera sentimento de revolta em Tonini? Ela ainda destacou a tristeza do missionário ao lhe relatar a renúncia.

Muito embora o título da obra de memória de Corazza sugira que ele tenha sido cauteloso, não é o que se observa em sua narrativa. Existe uma explicação para o título "silêncio prudente". Foi publicado no ano 2000, logo após a morte de Tonini e, três anos após a morte de Pattarello. É como se Corazza dissesse que o silêncio que havia sido prudente não era mais necessário. A partir de então ele escreveu o que sabia: os bastidores da missão da qual ele mesmo foi testemunha. Assim, Corazza em suas memórias aponta Pattarello como quem conspirou contra Tonini, quando registrou:

Em Tocantinópolis, sede da missão orionita, o slogan paulino "é bom desejar ser bispo" era notório e não faltavam pretendentes, embora todos soubessem que já havia um preconizado da cúpula à espera. Numa carta escrita pelo próprio provincial da época, Pe. Pattarello, a um colega amigo, Pe. Pacífico, aquele prometia uma boa quantia em dinheiro, para a construção da igreja de Araguaína, exigindo claramente o troco: "façamos cair a pedra no peão e o reizinho (padre Tonini) cairá sozinho" Grifo nosso (CORAZZA, 200o, p. 6I). 


\section{C) HISTT́ÓRICA}

Como observa-se, Corazza deixou claro o que estava acontecendo no final da década de 1950 no interior da missão orionita na região: disputa pelo poder que se materializou em intrigas. Intrigas que foram implantadas pelo provincial dos orionitas no Brasil à época, Pattarello, contra o administrador apostólico dos orionitas em Goiás, Tonini. Corazza foi direto em seu registro e sem rodeios, expôs os bastidores da missão.

Primeiro, ele se refere ao ano de 1959, momento em que Tonini era o administrador apostólico da Igreja Católica na região. Administrador apostólico dentro da hierarquia da Igreja é um cargo provisório, geralmente o administrador apostólico governa até a escolha do bispo, seu substituto. Ou seja, o mandato de Tonini como administrador estava chegando ao fim, o processo de nomeação de um bispo para a Igreja da região seria questão de tempo. Tonini poderia ser nomeado bispo e confirmado no cargo em caráter definitivo ou escolhido outro sacerdote entre os religiosos para, como bispo, administrar a Igreja da região.

Anos antes, Pattarello havia perdido a disputa pelo cargo de administrador apostólico para Tonini e, em I959, ao que parece, começou então a se movimentar para tirar Tonini do cargo e da missão na região e "acelerar" a escolha de seu substituto, ele próprio, acredita-se. Corazza registrou que havia pretendentes para o cargo, certamente Pattarello era o mais forte candidato. Corazza registrou, portanto, que Pattarello escreveu a carta à Mecozzi, missionário orionita em Araguaína, importante centro da missão.

Na correspondência, Corazza registrou que Pattarello pediu apoio de Mecozzi para o plano de "derrubar" Tonini do cargo de administrador para que fosse aberta a sua sucessão e, consequente, a nomeação de um bispo, ao que parece, ele mesmo desejava sê-lo e, surpreendentemente, condiciona o pedido de apoio de Mecozzi ao envio por parte dele, Pattarello, de recursos financeiros para a construção da igreja em Araguaína. Ou seja, Pattarello tentou, segundo Corazza, subornar Mecozzi, em troca de apoio para seu plano contra Tonini que ele chamou de "reizinho". Com esse termo, a intenção de Pattarello era inferiorizar e ridicularizar Tonini.

Em sua narrativa autobiográfica, Corazza traz os bastidores em torno da congregação orionita com clareza. Ele apresenta as intrigas como uma espécie de história paralela à história oficial da missão em Goiás. Sobre o entendimento da história a partir de estudos autobiográficos, Lígia Maria Leite Pereira reflete:

O escrito autobiográfico, nos lembra Contardo Calligaris, pressupõe uma cultura em que o indivíduo se coloque acima da comunidade a que 


\section{C) HițTó}

pertence, e conceba sua vida como uma aventura a ser inventada, e não como um destino pré-determinado a ser cumprido. Além disso, se é certo que sempre se escreveram histórias de vida, a ideia de que a vida é uma história surgiu com a era moderna (PEREIRA, 2000, p. II7).

Conforme Pereira, o escrito autobiográfico faz com que o indivíduo conceba a sua vida como uma aventura a ser inventada e, a narrativa autobiográfica passa a ser construída como uma verdadeira história, a história encadeada pelo próprio narrador. Foi essa a história construída por Corazza, a história de sua vida como sacerdote orionita na região da missão objeto deste estudo. Como observado, na "proposta" de Pattarello, ele escreveu sobre a necessidade de fazer "cair a pedra no peão". Segundo Corazza, o peão no caso era ele próprio, à época considerado homem de confiança de Tonini. Acreditou Pattarello que ao atingir Corazza, atingiria também Tonini e esse se desestabilizaria. Foi essa, então, a estratégia: atingir Corazza para conseguir "minar" o trabalho de Tonini.

Ao que parece, foi o que aconteceu. Do momento em diante o missionário Corazza foi perseguido pelo provincial Pattarello, sendo inclusive, chamado para uma conversa com o Núncio Apostólico no Brasil à época, conforme ele registrou em suas memórias: "Para complicar a situação, chegou um telegrama de Dom Alano: Pe. Corazza, o Núncio Dom Lombardi espera-o" (CORAZZA, 2000, p. 63).

Corazza foi convocado por ninguém menos que o Núncio Apostólico no Brasil, o representante do Papa no país. Certamente para se explicar sobre a situação da missão orionita na região. Infelizmente, Corazza não relatou em suas memórias o conteúdo da conversa. Em seu registro ele próprio destacou a opção de não comentar. Arrisca-se inferir que a conversa não pôde ter outro motivo que não um pedido de explicação sobre as intrigas no interior da missão orionita em Goiás. Estaria Pattarello, como provincial dos orionitas no Brasil, implantado intrigas sobre a missão, seus membros e Tonini? Infere-se que é perfeitamente possível que sim. O fato é que significativas mudanças ocorreram após o encontro de Corazza com o Núncio Apostólico. Segundo Corazza:

Quando voltei da Nunciatura o clima estava para lá de nebuloso. Estava turvo. Eu (o peão), transferido para a Sicília. D. Tonini (o reizinho) tombado. Era o cheque-mate. Não para os dois, que tiveram a graça e a força de conservar a fé. O cheque-mate foi para a missão orionita goiana, atingida em cheio. E como! (CORAZZA, 200o, p. 63). 


\section{C) HițTó}

Corazza registrou que ao voltar para Goiás após o encontro com o Núncio Apostólico, deparou-se com a realidade: ele próprio estava transferido para a Itália e, Tonini "tombado", ou seja, derrubado. Assim como ocorreu com Foli que anos antes foi transferida para Santa Catarina. Tonini renunciou ao cargo de administrador apostólico em 1959, indo morar não só longe de Tocantinópolis, mas longe do Brasil, no Uruguai. Corazza chamou as transferências de "xeque-mate". Considera-se inferir que essas transferências estiveram na base dos acontecimentos que provocaram ressentimentos em Corazza e que décadas depois levou-o a considerar Pattarello como o perseguidor dele próprio como também dos outros missionários do grupo de Tonini.

Mas por que os ressentimentos de Corazza foram tomados como objeto de reflexão neste estudo? Quanto à problemática dos ressentimentos que podem ser tomados como reflexão na pesquisa histórica, Pierre Ansart considera que ao historiador, também é válido abordar essa temática cuja observação é feita por outras áreas de estudo como, por exemplo, a psicanálise. Segundo Ansart, para esse tipo de abordagem, é necessário "considerar os rancores, as invejas, os desejos de vingança e os fantasmas da morte, pois são exatamente estes [os] sentimentos e representações designados pelo termo ressentimento" (ANSART, 2004, p. I5), e que, segundo acredita-se, esses fatores sempre ocupam espaço na vida dos seres humanos, independente de sexo, crença e ideologias, elementos que em alguns casos, por serem fenômenos humanos, terminam por se tornar, também, objetos da história.

Sobre as transferências, ao que parece, foi a vitória de Pattarello. Ele conseguiu "se livrar" de Tonini e foi uma "vitória" completa, visto que esse último foi designado para outro país: Uruguai. Pattarello não iria mais lidar, daquele momento em diante, com Tonini. Corazza encerrou o último registro explicando que o "xeque-mate" de Pattarello não foi só no grupo de Tonini, mas na missão orionita como um todo, no trabalho realizado por eles até então. Ele mesmo esclarece o que havia acabado de acontecer, quando inconformado, registrou: “Acredite quem quiser. Já estava tudo decretado. Não era possível que aquilo fosse verdade. Desmoronava tudo, um trabalho levado a efeito com tanto amor e sacrifício" (CORAZZA, 200o, p. 6I).

Conforme se observa, Corazza registrou que tudo que havia acontecido, ou seja, as transferências e a própria renúncia de Tonini tinha sido resultado de um projeto, é possível essa interpretação devido ele ter escrito "já estava tudo decretado". Mas decretado por quem? Por Pattarello, o superior dos orionitas no Brasil. Corazza, inconformado, registrou que tudo estava desmoronado, foi como se dissesse: destruído. E encerrou seu registro afirmando que 


\section{G) CitșTórica}

o trabalho realizado pelo grupo de Tonini do qual ele fazia parte, teria sido feito com muita dedicação, amor e sacrifício.

Foi mais que um "desabafo" de Corazza, ao que parece, ele expôs um enorme ressentimento com Pattarello. Seria possível inferir que a interferência de Pattarello no grupo de Tonini do qual Corazza fazia parte e as consequentes investidas teriam provocado tamanho ressentimento em Corazza? Pattarello, por suas investidas e perseguições, provocou traumas na vida de Corazza? Marc Ferro, em seus estudos sobre o ressentimento na história, reflete que na origem do ressentimento, seja no aspecto individual ou de grupo, encontra-se, na maioria das vezes uma ferida ou mesmo uma violência que algum indivíduo sofreu, o que pode gerar um trauma.

Quem se considera vítima e que por algum motivo não teve condições de reação, na maioria das vezes alimenta o ressentimento, uma mágoa, um inconformismo. Esses últimos elementos alimenta um desejo de vingança e que se não executada, "atormenta" a suposta vítima sem trégua, até um dia explodir. A partir de Ferro, infere-se que esse ressentimento de Corazza, seu inconformismo, "explodiu" na forma escrita, o que deu origem aos seus registros de memória, objeto deste estudo. Essa "explosão" do ressentimento pode ser acompanhado, ainda, de estratégias de desqualificação de quem foi considerado pela vítima, como "opressor" (FERRO, 2009, p. 59).

Ainda sobre a transferência de Corazza para a Itália, importante observar que ele se considerou um exilado, conforme registrou:

Em Palermo, na Água Santa, quartel central da máfia, a congregação tem um internato. Ali fui cumprir meu exílio, como assistente dos filhos dos mafiosos. Tanto em Palermo como em Messina fiz uma ótima experiência pedagógica (CORAZZA, 2000, p. 64).

O exílio é a condição em que a pessoa é enviada ou decide ir para outra região ou país contra a sua vontade, geralmente, fruto de perseguição no país de origem. Corazza sentiu-se exilado quando voltou para o seu país - Itália - contra a sua vontade - pois desejava continuar seu trabalho na missão orionita em Goiás. Ao sentir-se exilado, Corazza pareceu se vitimizar, pelo fato de ter sido transferido por Pattarello, visto ter sido esse último o responsável pela situação. Estaria Corazza, considerando -se vítima de Pattarello?

Sobre estratégias de vitimização, Tzvetan Todorov reflete que "ninguém quer ser vítima, isso não tem nada de agradável; em contrapartida, todos querem ter sido; eles 
aspiram ao estatuto da vítima" (TODOROV, 1999, p. 225). Ao se considerar um exilado o que de fato não foi visto apenas ter sido transferido de um país para servir à congregação em outro, Corazza, na verdade, se vitimizou como uma estratégia, acredita-se, para enquadrar ainda mais Pattarello como uma espécie de "vilão" do "sofrimento" que ele sentia em virtude de sua transferência da missão em Goiás. Ou seja, a partir de Todorov, infere-se que, ao não se conformar com sua transferência para a Europa, mesmo que tenha se considerado perseguido por Pattarello, Corazza se aproveitou da situação para se considerar vítima de Pattarello.

Corazza em seus registros, apresentou suas experiências quando da transferência para a Itália, na verdade, o retorno para o seu país, visto ser italiano. Lá, ele diz ter aproveitado outros trabalhos. Corazza registrou, ainda, o fato de ter algumas de suas correspondências interceptadas e, portanto, violadas, visto que foram abertas sem seu consentimento, por membros da congregação orionita. Sobre essas correspondências ele registrou:

Dom Carlo Pensa, superior geral, visitou a missão goiana e não se conformava com minha transferência para a Sicília. Lamentava meu silêncio. Acontecia, porém, que minhas cartas não lhe eram entregues. Segundo a versão do então secretário dele, Pe. Zambarbieri, era para não apressar a morte do superior geral, já idoso. Aquele falso zelo foi por mim rebatido: O senhor secretário que me perdoe. Sempre ouvi dizer que a verdade, por mais dura que seja, jamais mata alguém. Ao contrário, abre os olhos dos vivos para evitar as iniquidades, as injustiças, as calúnias (CORAZZA, 2000, p. 64).

Interessante observar que Dom Carlo Pensa, então superior geral dos orionitas em Roma, foi o primeiro sucessor de Dom Orione, tendo sido seu "braço direito" por longo período (PATTARELLO, I985, p. 28). Ao registrar que o superior dos orionitas não havia se conformado com sua transferência para a Itália, acredita-se que as movimentações de Pattarello na missão goiana não foram do conhecimento do superior que morava em Roma. Corazza descobriu, a partir desse encontro com o Pensa, que as cartas que ele escrevia para o superior geral não chegavam a suas mãos, foram, portanto, desviadas.

Ao criticar esses registros de memória de Corazza, questiona-se se, de fato, algumas correspondências de Corazza foram mesmo interceptadas por alguns religiosos de sua congregação. Por que ele em seus registros não legou mais informações sobre esse episódio? 


\section{G) CitșTórica}

Quando da investigação que deu origem a este estudo, essa preocupação foi motivo de reflexão. Mas ainda assim, acredita-se, portanto, ser preciso analisar esses registros de memória sobre as supostas interceptações de suas cartas como ele escreveu, como o seu testemunho para os acontecimentos que ele viveu, pois assim como Ecléa Bosi:

Não cabe aqui interpretar as contradições ideológicas dos sujeitos que participaram da cena pública. O que me chama a atenção é o modo pelo qual o sujeito vai misturando na sua narrativa memorialista a marcação pessoal dos fatos com a estilização de pessoas e situações (BOSI, I994, pp. 458-459).

Observa-se que ao registrar que algumas de suas correspondências foram desviadas, ele terminou por expor ao máximo a congregação orionita. Portanto, há de se observar que nos registros de memória de Corazza, ele não separou o "eu" do "meio" em que ele convivia. A escrita dele, portanto, expôs a todo momento a congregação orionita e as práticas exercidas por alguns de seus superiores. A questão da relação entre o indivíduo e os grupos sociais a que são vinculados pode ser refletido a partir de estudos autobiográficos. Sobre essa relação, Maria Lígia Pereira reflete:

Os documentos pessoais apresentam algumas distinções entre si, a exemplo das autobiografias e memórias. Trata-se de uma questão de intenção: o autor quis escrever a história de sua pessoa ou a de sua época? Nas memórias, o autor se coloca como testemunho de seu tempo. Se não há como abandonar o ponto de vista individual, o objeto do discurso é algo que ultrapassa em muito o indivíduo, para ser a história dos grupos sociais e históricos aos quais ele pertence ou pertenceu (PEREIRA, 2000, p. I24).

Corazza deixou registrado em suas memórias que procurou informar ao superior geral que residia em Roma, sobre os acontecimentos que estavam em curso na missão goiana. A que se deduzir, ainda, que as mesmas correspondências podem ter chegado às mãos do superior geral. E que, ao julgar os conflitos que ocorriam entre Pattarello e Tonini no contexto da missão goiana, Dom Carlo Pensa ter tido uma postura favorável à Pattarello. E tempos depois, ao encontrar-se com Corazza, ter assumido uma postura de desentendido, ou de desconhecimento do que ocorria entre os orionitas em Goiás.

Passados três anos das transferências, Corazza retornou da Itália ao Brasil, era o ano de 1962. Estava encerrado o que ele considerou como seu "exílio" na Europa, longe da missão 


\section{C) HitsớróRICA}

orionita em Goiás. Ao chegar ao Brasil, foi enviado novamente para a missão goiana na cidade de Araguaína. No mesmo ano, Corazza se incumbiu de buscar mecanismos para a criação de uma escola orionita na cidade e, na ausência de recursos para a manutenção da mesma, registrou em suas memórias que optou por buscar entre alunos e pais, além de moradores de melhor condição financeira da cidade, recursos para manter a escola a ser criada (CORAZZA, 200o, p. 48).

Importante observar que independente da ideia de Corazza de ter buscado apoio financeiro para a criação da escola, e mesmo a congregação orionita deter instituições de caráter exclusivamente filantrópico, surgiu no espaço de Araguaína e região à época, um "poderio econômico" dos orionitas, o que fez surgir daquele momento em diante, instituições como escolas, hospitais e até nos dias atuais, faculdades. Toda essa atuação institucional dos orionitas na região, como acredita-se, não seria possível com base em ações filantrópicas, exceto quando utiliza-se desse discurso de filantropia para conseguir benfeitores em outras regiões do mundo, no caso dos orionitas, na Europa de então.

A escola, à época, não poderia cobrar mensalidades. Estabeleceu-se, novamente, um novo conflito entre Corazza e Pattarello que no contexto ainda era o provincial dos orionitas no Brasil. Pattarello, segundo Corazza, interviu nos planos sobre a escola, conforme registrou: "A congregação através de seu representante, o provincial padre Pattarello, foi contra aquele projeto" (CORAZZA, 200o, p. 7I). Pattarello, ao ser contra o projeto para a escola orionita em Araguaína, estaria novamente perseguindo Corazza? Acredita-se que sim. O fato é que Corazza acreditou que sim. Dois anos depois do seu retorno ao Brasil, em I964, com apoio do prefeito da cidade, alunos, pais de alunos e doadores locais, Corazza conseguiu fundar a escola que recebeu o nome de Ginásio Santa Cruz 9 .

Passados alguns anos, Corazza sofreu um acidente na BR-I53 próximo a cidade de Guaraí. No veículo estavam três orionitas, Corazza, padre Viana e irmão Macário. O carro, segundo ele, capotou na rodovia e, dos três ocupantes do veículo, Corazza foi o que sofreu mais escoriações. Em suas memórias, ele escreveu que foi transferido para a capital, Goiânia, onde recebeu socorro médico (CORAZZA, 200o, p. 75). Depois do acidente, Pattarello, alegando que Corazza precisava "descansar" do trabalho de diretor da escola em Araguaína

\footnotetext{
${ }^{9}$ Essa escola, atualmente um colégio, é o principal estabelecimento de ensino privado da cidade de Araguaína e um dos principais do estado. Tem a tradição de formar a elite da cidade e região. É um estabelecimento de ensino praticamente destinado às camadas mais elitizadas da cidade, muito embora ofereça bolsas de estudo a alguns poucos alunos, os de menor condição financeira. Vale lembrar que a congregação dos padres orionitas é reconhecida mundialmente como uma congregação pautada na caridade e humildade de seus membros, o próprio lema de seu fundador, Dom Orione, foi a caridade.
} 


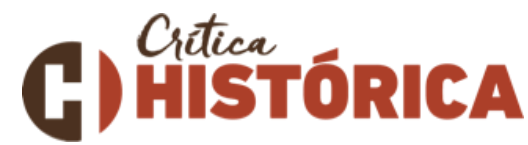

e com essa "justificativa" transferiu-o para o pequeno povoado de Ananás, outra cidade da missão orionita na região. Lá, Corazza registrou ter passado por dificuldades, segundo ele:

Mais um mês e livrei-me das muletas. O provincial, padre Pattarello, mandou-me então substituir o padre Raffa, em Nazaré. Ali permaneci durante seis meses, com alimentação precária, sem ter onde tomar as refeições regularmente. Exceto aos domingos, quando a esposa do prefeito, Dona Ivone, me trazia um almoço especial. (CORAZZA, 200o, p. 76).

Corazza, em plena recuperação do acidente, foi transferido por Pattarello para um pequeno povoado, onde certamente não teve condições para se recuperar nem fisicamente, nem psicologicamente do acidente. Ressentido da transferência, relatou as dificuldades que ele enfrentou. O fato de Pattarello tê-lo transferido ainda em momento delicado de sua saúde, e devido o histórico de embates que ambos já haviam tido, leva a acreditar que o mesmo era, de fato, perseguido. Corazza ainda registrou que nem mesmo alimentação adequada tinha acesso. Quanto à interferência da esposa do prefeito em favor de Corazza, pode-se estabelecer duas hipóteses: foi simplesmente um gesto de caridade humana ou, ainda, uma atuação político-religiosa do poder público municipal, através de sua primeira dama, à época, para "colher" os "louros" junto à sociedade, por ajudar o padre orionita.

Ainda sobre a transferência de Corazza para Ananás, em um momento considerado delicado de sua saúde, fato atribuído à Pattarello, reforça a interpretação de que as memórias de Corazza foram movidas, na sua totalidade, por ressentimentos dele à Pattarello. Em nenhum momento Corazza retrata Pattarello, senão por uma menção negativa. Por que Corazza registrou suas memórias sempre por esse viés? Como entender as sucessivas menções negativas de Corazza em relação à Pattarello? Sobre essa questão, David Konstan infere que o ressentimento "é uma noção complexa e bastante difícil de precisar (KONSTAN. 2004, p. 6I).

Ao analisar os registros de memória de Corazza, chegou-se à conclusão de que ele a todo momento atribuiu uma imagem negativa à Pattarello, ou seja, imagem negativa do outro, mas nunca dele próprio. Ele se autobiografou como um missionário corajoso, destemido, forte, sem mácula ou problemas de qualquer natureza. Ele e o grupo de missionários aliados de Tonini, são lembrados como homens sem desacertos. Maria Lígia 


\title{
C) CitsTTórICA
}

Leite Pereira em suas reflexões sobre autobiografias, observa que é muito comum a ausência de erros na vida de quem escreve sobre si. Segundo ela:

\begin{abstract}
A maioria das histórias de vida consiste em verdadeiras apologias. Há escassez de atos errados ou imorais, de práticas injustas ou violentas, de comportamento fraudulento de quase todo tipo de parte do escritor. A maior parte das histórias de vida tentam falar com uma única voz, sem contradições e sem oponentes. Partes quase inteiras da vida são deixadas de fora, especialmente os episódios dolorosos ou questionáveis que poderiam trazer danos à imagem do narrador (PEREIRA, 2000, p. I24).
\end{abstract}

Conforme Pereira, acontecimentos que possam colocar em dúvida o comportamento da pessoa que narra sobre a sua própria vida, são silenciados na maioria das autobiografias. Infere-se que é perfeitamente possível ter havido passagens da vida de Corazza e não só dele, mas também de Tonini, Mecozzi e Foli, que poderiam levar a questionar a imagem e a própria história de vida dos mesmos. É certo inferir que nos registros de memória de Corazza não se retratou nada que desabonasse a conduta nem dele nem do grupo de missionários a que ele pertenceu, o grupo de Tonini. Mas nos registros de memória de Corazza, objeto deste estudo, e não só desse último, mas de seus companheiros, eles apresentaram biografias incorruptíveis.

Logo após sua passagem pelo povoado de Ananás, eis que ocorreu nova transferência de Corazza, dessa vez para Araguatins, outro centro da missão orionita, lá residiu mais um período, segundo ele, ainda em recuperação médica (CORAZZA, 200o, p.79). Anos depois, em I97I, Corazza voltou para Araguaína e retornou ao cargo de diretor do Ginásio Santa Cruz. No mesmo ano, segundo ele, a secretaria de educação de Goiás ofereceu uma parceria com a escola orionita, seria um "convênio modelo" para outras escolas de Goiás. Corazza fechou o acordo, mas com a condição de que enquanto a verba não fosse liberada pelo governo estadual, a escola orionita de Araguaína continuaria recebendo o apoio financeiro de seus alunos, pais e doadores locais.

Segundo ele, ocorreu uma denúncia na capital, Goiânia, afirmando que estava irregular o acordo e que o Ginásio Santa Cruz estava na ilegalidade. Segundo Corazza, ele chegou a ter sua ordem de prisão solicitada à época, sendo que logo a mesma foi revogada (CORAZZA, 200o, p. 78). Sobre o pedido de prisão, acredita-se que foi uma decisão precipitada das autoridades, ou por desconhecerem os reais fatos ocorridos, ou ainda, a supervalorização da denúncia, com objetivo de macular a imagem do missionário. 


\section{G) AitșTórICA}

Em seus registros de memória, Corazza insinuou que a denúncia foi fruto de uma armação contra ele, mas não chegou a mencionar diretamente a suspeita sobre a participação de Pattarello nesse último caso. De qualquer forma, sendo autor da denúncia ou não, Pattarello, segundo Corazza, se aproveitou da situação:

Padre Pattarello, o Provincial, não perdeu a oportunidade. Aplaudiu a confusão e convocou uma reunião de todo o corpo docente da escola, sem meu conhecimento, convidando também o Superior Geral da Congregação, Dom Zambarbieri, que tinha vindo da Itália e estava de passagem por Araguaína, na ocasião. A decisão final foi uma ordem irreversível: Remígio tinha que sair. E assim aconteceu. Quando eu estava no entroncamento para embarcar, Leonino Caiado, então governador de Goiás, passou ocasionalmente e, vendo-me ali, parou o carro e disse: "Padre Remígio, os teus chefes são piores que Coronéis, não pude fazer nada". Obrigado, governador. Não se escandalize. Na religião a política é assim, às vezes. Quando não é pior. Para tranquilizar meus ânimos, viajei para Belém, como hóspede de confrade amigo, padre Hélio Frizon (CORAZZA, 200o, p. 79).

Conforme exposto por Corazza, Pattarello se "aproveitou" da denúncia envolvendo a suposta irregularidade do convênio entre a escola orionita e a secretaria de educação de Goiás, e novamente entrou em conflito com Corazza. Esse último registro de Corazza, reforça a interpretação de que Pattarello nada fazia para evitar entrar em choque com Corazza, o que reforça a interpretação de que esse último era, em maior ou menor grau, perseguido por Pattarello. Seria então, essa postura de Pattarello - de não evitar entrar em conflito com Corazza - a maior causadora de tanto ressentimento nesse último? Acredita-se que sim.

Ao que parece, Pattarello não tinha mesmo afeto algum por Corazza, e pior, não perdia uma oportunidade se quer, para enfrentá-lo. Foi essa postura de Pattarello a responsável pela origem dos ressentimentos de Corazza? Pierre Ansart, quando reflete sobre a memória e sua relação com os ressentimentos, infere que "dificilmente se pode aceitar a hipótese de que um sentimento, do qual sublinhamos a intensidade e a força, não tenha consequências nem manifestações nas condutas dos indivíduos" (ANSART, 2004, p. 2I).

Após a denúncia, segundo Corazza, uma reunião foi convocada por Pattarello para decidir o seu futuro como então diretor da escola. O encontro teve a participação do superior geral dos orionitas, isso mesmo, o orionita número um da congregação no mundo, estava de passagem por Araguaína à época. Considera-se que mais surpreendente que a participação 


\section{C) HististóricA}

do superior dos orionitas na reunião, foi o fato da denúncia ter ocorrido justamente durante a visita do mesmo à cidade de Araguaína. Coincidência, por sinal, muito infeliz para Corazza.

Na reunião decidiu-se por seu afastamento. Diga-se de passagem, pela segunda vez Pattarello conseguiu afastar Corazza da direção da escola orionita de Araguaína. Ainda mais emblemática foi a entrada em "cena” do então governador de Goiás, Leonino Caiado, que segundo Corazza, também estava de passagem por Araguaína no momento. Corazza em sua narrativa registrou que o governador teria lhe dito que não tinha tido condições de ajudá-lo e que os orionitas, superiores de Corazza, eram "piores que coronéis" (CORAZZA, 200o, p. 8I).

Observa-se no diálogo entre Corazza e Caiado, o que pode ser, por parte dos dois, a exposição da congregação orionita da pior forma possível, como um ambiente “contaminado" por disputas e intrigas. Dessa forma, Corazza foi novamente atingido por Pattarello. Ele registrou os planos de Pattarello na reunião: a decisão do superior da congregação foi afastá-lo da direção da escola, novamente. Em seus registros de memória, Corazza apresentou a sua verdade sobre os fatos que ele viveu. Sobre os mecanismos de construção da verdade de si mesmo nos escritos autobiográficos, reflete Michel Foucault:

\footnotetext{
A escrita como exercício pessoal feito por si e para si é uma arte da verdade díspar; ou, mais precisamente, uma maneira racional de combinar a alteridade tradicional da coisa já dita com a singularidade da verdade que nela se afirma e a particularidade das circunstâncias que determinam seu uso (FOUCAULT, 1983, p. 15I).
}

Segundo Foucault, a escrita de si termina por ser o que ele chama de "arte da verdade”. A verdade que é construída e constituída pelo próprio narrador da sua vida, no caso em questão, o missionário orionita Corazza. Ainda sobre esse mecanismo de construção da verdade pelo narrador, Foucault acrescenta que a verdade construída pelo narrador estará a serviço das circunstâncias que irão orientar o uso dela. No caso, a verdade que foi elaborada por Corazza esteve e ainda está circunstanciada ao uso que ele pretendeu dar a ela: mostrar que foi perseguido por Pattarello e como foi perseguido pelo mesmo.

Mas Corazza, missionário orionita a quem se atribui personalidade forte, destemida e corajosa, terminou por se encontrar anos depois com Pattarello. O encontro foi no ano de 197I. Esse que foi, segundo seu registro de memória, o último encontro entre os dois, ocorrido em Goiânia. Sobre o momento ele registrou: 


\section{C) HististóricA}

Quando a tempestade amainou, dois meses eram passados. Telefonaram ao padre Hélio, marcando um encontro comigo em Goiânia. Era uma manhã nublada. Corria no ar uma brisa suave. O encontro aconteceu por trás da Igreja de São Paulo Apóstolo. Veja antes este memorando, adiantei-me. Depois de ler os oito itens o padre provincial gaguejou: Como é que você ainda recorda tudo isso? São feridas que você abriu. Não houve cura, nem lenitivo. Estão ainda abertas, sangrando. Chorando, o Provincial pediu-me para ficar em Goiânia. Para que? Perguntei. Padre Tonelli estava cansado e idoso, precisava de cuidados médicos em São Paulo. Antes de sair, quis que eu o substituísse na Paróquia. Diante disso assumi a Paróquia de São Paulo Apóstolo, em Goiânia. Antes de tomar posse como vigário em Goiânia fui visitar meus parentes na Itália (CORAZZA, 2000, pp. 79-80).

Corazza foi chamado por Pattarello para a conversa. É surpreendente o gesto de Corazza: relatou que entregou um "memorando" para Pattarello, certamente um papel pontuando tudo que Pattarello já havia feito de ruim para com ele Corazza e os missionários do grupo de Tonini. Ele registrou que foram oito os itens ali esboçados. Observou que Pattarello impressionou-se com o fato de Corazza se lembrar de todos os acontecimentos que colocaram os dois em choque. Corazza respondeu que foram "feridas" abertas por Pattarello e pior, que naquele momento do encontro, em I97I, ainda "sangravam".

Corazza expôs todo seu ressentimento por Pattarello, por tudo que ele havia feito contra ele e contra os primeiros missionários, entre eles Tonini, Mecozzi e Foli. Ao que parece, o encontro foi um "acerto de contas" entre os dois. Corazza, visto como destemido, o homem da "linha de frente" e, na frente dele naquele momento, em Goiânia, estava ninguém menos que Pattarello, seu "algoz". Por que, tanto tempo depois dos acontecimentos da década de 1950, Corazza, ao escrever seus registros de memória, pareceu não ter superado suas mágoas e ressentimentos para com Pattarello?

Sobre essa dificuldade de Corazza em superar seus ressentimentos por Pattarello, David Konstan reflete que: "mesmo em seu sentido popular, o ressentimento parece sugerir um estado ou sentimento persistente, em vez de uma reação a um estímulo particular e imediato" (KONSTAN, 2004, p. 62). De fato, a partir de Konstan, infere-se que os ressentimentos de Corazza por Pattarello não se apagaram numa distância temporal de duas décadas, eles persistiram. 


\section{C) HististóricA}

Corazza registrou que Pattarello chorou diante dele. Esse choro pode ser interpretado como arrependimento? Sim, pode. Mas também pode ser interpretado como não arrependimento, visto que ele não se desculpou, ou melhor, não pediu perdão à Corazza. De Pattarello naquele instante, Corazza só registrou o choro. Não se pode atribuir um significado mais claro para o gesto de chorar de Pattarello, exceto inferir que é possível que tenha se arrependido. Mas ainda é possível afirmar que Pattarello poderia ter dado um "passo" adiante e aproveitado o momento para reconhecer que havia errado, agido mal ou, na linguagem religiosa visto que eles eram religiosos, cometido muitos, muitos pecados. Mas não o fez.

O registro de memória de Corazza do último encontro entre os dois passou à história com o gesto do choro de Pattarello e seu consequente silêncio. Não houve, portanto, pedido de perdão de Pattarello à Corazza. Muito menos Corazza se adiantou para perdoá-lo. Muito pelo contrário, a partir da narrativa de Corazza, no momento ele entregou um documento que ele chamou de "memorando" para Pattarello, acredita-se, uma lista de suas "maldades". É possível também, que o choro de Pattarello não tenha nem sequer existido. Ou ainda, se existiu, não ter sido verdadeiro, disso não saberemos.

Ao registrar que não houve pedido de perdão de Pattarello e, consequentemente, arrependimento, não seria essa uma estratégia de Corazza de se auto absolver no conflito com Pattarello? De igual forma não saberemos, são só possibilidades. Sobre esses questionamentos e a impossibilidade de elucidá-los com muito mais precisão, concorda-se com Pierre Ansart de que "certamente é muito mais difícil traçar a história de ódios do que a história de fatos objetivos" (ANSART, 2004, p. 2I).

A partir do registro de memória de Corazza, não houve uma manifestação pública de perdão de Pattarello à Corazza no último encontro entre os dois. Então, se de fato não houve pedido de perdão, como entender a atitude de Pattarello frente à Corazza? Como também o fato de Corazza não ter se adiantado e, vendo Pattarello chorar diante dele, não lhe oferecer o perdão? Paul Ricoeur, em seus estudos sobre o perdão, na condição histórica, não descarta a possibilidade da reconciliação com o passado por meio da perspectiva escatológica do perdão, mas alerta:

O perdão, se tem algum sentido e se existe, constitui o horizonte comum da memória, da história e do esquecimento. Sempre em segundo plano, o horizonte foge ao domínio. Ele torna o perdão difícil: nem fácil, nem impossível. Ele imprime o selo do inacabamento na empreitada inteira. Ele é tão difícil de se dar e de se receber quanto de se conceituar. A trajetória do 


\section{C) CitsistórICA}

perdão tem sua origem na desproporção que existe entre os dois polos da falta e do perdão (RICOEUR, 2007, p. 465).

Ricoeur questiona se o perdão de fato existe e se haveria nele algum sentido. Ele diz que o perdão é difícil. Se a chave do perdão estaria no "desligamento" do sujeito com a sua ação, convém realmente concordar com Ricouer que o perdão é difícil. Tanto é difícil que Pattarello não pediu perdão à Corazza, limitou-se, segundo esse último, a chorar no último encontro entre os dois. Ninguém mais do que Pattarello sabia e deveria ter consciência de tudo que já havia feito contra os missionários. Tão difícil ainda que também Corazza não se adiantou a oferecer-lhe o perdão. Por que Paul Ricoeur teorizou que o perdão na história é difícil? Ele reflete a respeito dessa dificuldade ao inferir:

Se a justiça é mesmo para ser feita, sob pena de que a impunidade dos culpados seja consagrada, o perdão somente pode se refugiar em gestos incapazes de se transformarem em instituições. Esses gestos que constituiriam o incógnito do perdão designam o lugar inelutável da consideração devida a todo homem, singularmente ao culpado (RICOEUR, 2007, p. 466).

A partir da reflexão de Ricoeur, fica claro o porquê que o perdão é difícil. Ele diz que a crença na justiça e na necessidade de que essa impere, faz com que o perdão se torne um "gesto incapaz". Assim sendo, a recusa de Pattarello em pedir perdão à Corazza limitando-se a chorar diante desse último e, o consequente fato de Corazza não se adiantar em oferecer perdão à Pattarello representaria, então, da parte de ambos, esse desejo de que a justiça, afinal, fosse feita? E sendo assim, a justiça feita, o gesto do perdão seria incapaz de pôr fim àquela pendência entre os dois? A partir da reflexão de Ricouer, acredita-se que sim.

De toda sorte, a partir do registro de memória de Corazza, não houve perdão entre os dois orionitas. Para Ricoeur, o perdão, se existe, "quebra" a dívida, mas não a faria esquecer, pois para ele é um esquecimento relativo da dívida, não do fato em si. Então, segundo Ricouer, o perdão não é uma exigência, mas um pedido que pode enfrentar a recusa, o imperdoável, daí o perdão para ele ser possível, mas difícil. De fato, foi tão difícil para os dois orionitas que ele não existiu no último encontro. 


\section{(G) HitșTónICA}

\section{Considerações finais}

O propósito deste estudo foi desvelar os conflitos que ocorreram no interior da missão orionita, sob a ótica de um de seus missionários: Corazza. Pelo que ele revelou claramente ou nas entrelinhas mostrou, infere-se que sim, ocorreram perseguições e conflitos entre os missionários orionitas à época, com destaque para quem foi apontado por Corazza como uma espécie de "vilão" do processo: Pattarello. Por que Corazza apontou Pattarello como perseguidor? Porque ele narrou o que ele viveu no seio da missão, pois, assim como Walter Benjamim, acredita-se que "O narrador conta o que ele extrai da sua experiência - sua própria ou aquela contada por outros. E, de volta, ele a torna experiência daqueles que ouvem a sua história" (BENJAMIN, 1985, p. 197-22I).

O objetivo que se propôs desde o início foi observar a missão sob a ótica de Corazza e exclusivamente por intermédio dele. Por que privilegiou-se abordar os bastidores da missão pela ótica de Corazza? Porque as memórias de Corazza não podem estar senão associadas à missão orionita e seus membros, pois, assim como Ecléa Bosi, acredita-se que “A memória do indivíduo depende do seu relacionamento com a família, com a classe, com a escola, com a igreja, com a profissão; enfim, com os grupos de convívio e com os grupos de referência peculiares a esse indivíduo" (BOSI, I994, p. I7).

Mas alguns problemas podem ser apontados ao criticar o uso das narrativas de memória de Corazza como fonte única para estabelecer-se generalizações como, por exemplo, acreditar que realmente ocorreram perseguições e conflitos entre alguns orionitas. Mas, ao mesmo tempo, as narrativas de memória de Corazza podem não ter sido o espelho real dos fatos ocorridos à época. Mas a escolha delas, do ponto de vista metodológico, se deu pelo fato de que Corazza foi o único que buscou mostrar a missão orionita pelo que sob a ótica dele, além de outras coisas, ela foi: ambiente de disputa e de perseguição implantada por um de seus mais iminentes membros: Pattarello.

Não se trata, portanto, de ter dado voz a um orionita que apenas "reclamou" de outro orionita. Mas alguém que da sua forma, expôs em detalhes o que ele assistiu e viveu. A verdade de Corazza, portanto, pode não ser a verdade universal de todos os missionários envolvidos na missão à época, mas é a verdade dele, e é justamente a verdade de Corazza, o objeto deste estudo. A verdade de Corazza, impregnada de ressentimentos, foi construída de forma lógica, a lógica que ele encontrou para desencadear sua narrativa, seus registros de memória. Ainda se considera importante inferir que, esses registros de memória de Corazza, suas verdades, podem conter ausências de detalhes minuciosos como datas precisas e etc. 


\section{C) HitsớT́RICA}

Essas ausências não comprometeram a capacidade reflexiva deste estudo, pois, acredita-se, em consonância com Ecléa Bosi, que:

Às vezes há deslizes na localização temporal de um acontecimento. Falhas de cronologia se dão também com acontecimentos extraordinários da infância e da juventude. Uns e outros sofrem um processo de desfiguração, pois a memória grupal é feita de memórias individuais (BOSI, 1994, p. 419).

Através da análise atenta das memórias escritas de Corazza como também diálogos com sujeitos que não participaram dos eventos da década de 1950, mas que deles ouviram relatos, essas narrativas corroboram para a interpretação de que, em maior ou menor grau, os bastidores da missão orionita terminaram por provocar mudanças significativas em seu andamento. Como abordado anteriormente, as duas maiores mudanças foram: a renúncia de Tonini e, segundo, as transferências a que foram submetidos os missionários que orbitavam a sua volta, entre eles, o próprio Corazza.

Qual a relevância, portanto, dos conflitos religiosos para a atuação missionária dos orionitas na região? Essa relevância é justamente a hipótese antes levantada pois, como foi possível perceber, a partir dos relatos de Corazza e um registro de Foli, viu-se que os missionários que estavam sob a influência de Tonini, inclusive o próprio Corazza, foram transferidos da missão em solo goiano, para outras regiões do país como Foli, outros como Tonini e Corazza, enviados para fora do país. O único que não foi transferido foi Mecozzi, à época designado como vigário capitular da prelazia, cargo que ocupou por um ano. Certamente, as transferências dos principais missionários resultaram numa mudança nos rumos da missão à época em Goiás. A saída desses missionários fez com que novos orionitas fossem deslocados para Goiás. A própria saída de Tonini, à época considerado o principal entre eles, abriu caminho para a nomeação do primeiro bispo para a região: Cornélio Chizzini.

Viu-se, ainda, neste estudo, que a primeira década da missão orionita na região revelou a importância de um missionário: Tonini. Como sabe-se, chegou a ser administrador apostólico na região objeto deste estudo e esteve cotado, ao que parece, para ser nomeado bispo de Tocantinópolis. Tonini não contou à época com as articulações de Pattarello que, segundo Corazza, de tudo fez para desarticular tanto o seu trabalho como administrador apostólico, quanto o grupo de missionários que estavam na sua zona de influência. O próprio Corazza, junto com Foli, foram transferidos da missão, Tonini, como sabe-se, renunciou em 


\section{C) CitsTTórICA}

1959 à direção da mesma, renúncia sobre a qual até seu último dia de vida não quis revelar de forma escrita.

Sobre a renúncia de Tonini, várias hipóteses podem ser estabelecidas. Primeiro, sabendo ele que a missão orionita na região estava vivendo dias difíceis, resultado, por exemplo, das disputas entre seu grupo e Pattarello, ter ele buscado cessar, com sua renúncia, a situação então enfrentada, em nome da paz entre os religiosos e zelo pela igreja da região. A segunda hipótese, talvez, a consciência de que não tinha forças suficientes para lutar contra as investidas de Pattarello, à época, provincial dos orionitas no país. Ainda pode existir uma terceira hipótese, de que Tonini possa ter renunciado ao cargo como estratégia de proteção à figura de Foli, pois, como escrito anteriormente, ao que parece, ambos alimentaram uma paixão até os últimos dias de suas vidas.

Sobre essa última hipótese, teria Tonini renunciado ao cargo, sobre pressão de Pattarello, para proteger a todos da revelação de um "escândalo" no interior da missão orionita à época? O "escândalo" de sua suposta paixão pela então freira, Foli? Seria esse, inclusive, o motivo para o silêncio de Tonini sobre o caso até os dias finais de sua vida? Mas por que então ele teve de renunciar ao invés de ser substituído? Como escrito anteriormente, Tonini despontava de prestígio na Igreja à época, sendo inclusive considerado o principal missionário na região. A sua substituição geraria instabilidade na missão ou, necessitaria de uma justificativa plausível por parte de seus superiores, no caso, no Brasil, o seu superior era ninguém menos que Pattarello. Infere-se que foi desse último que veio a pressão pela renúncia de Tonini, ao invés de uma simples substituição.

Sobre a renúncia de Tonini e os afastamentos de Corazza e dos demais missionários, qual a versão oficial da congregação para esses acontecimentos? Absolutamente nenhuma versão nunca foi dada, nem de forma privada, nem de forma pública. A congregação desde os anos iniciais da missão em Goiás sempre contou com mecanismos de divulgação de suas ações como uma revista. Eles poderiam, perfeitamente, terem utilizado essas publicações oficiais para explicar os acontecimentos envolvendo seus principais missionários, mas assim não o fizeram. Um silêncio surpreendente impera até à atualidade quando se refere aos acontecimentos envolvendo os missionários citados neste estudo. Esse silêncio, acredita-se, reforça a convicção de que esses acontecimentos envolvendo os orionitas no início da missão em Goiás - conflitos, perseguições, desavenças - representam momentos sobre os quais a congregação orionita no Brasil pretendeu e ainda pretende esquece, colocá-los como uma “página virada”. Por esse motivo, as versões de Corazza para esses acontecimentos se tornam fonte única para os eventos objetos deste estudo. 


\section{C) CitsistórICA}

Mas Corazza talvez tenha sido o missionário que mais sofreu com as perseguições de Pattarello. Segundo suas memórias, foi transferido várias vezes de lugar como também destituído de suas funções de diretor de escolas orionitas. Os registros de memória dele revelam as manobras praticadas por Pattarello de modo que a partir desses relatos, foi possível imaginar os acontecimentos com detalhes narrativos dignos de uma trama de cinema.

Em que pese o fato de que Corazza tenha sido o missionário que mais foi perseguido pelas investidas de Pattarello, Corazza não parece tê-lo enfrentado, revidado, com exceção das correspondências enviados ao superior dos orionitas em Roma e que, segundo ele, foram desviadas, Corazza não denunciou Pattarello publicamente à época. Como sabe-se, deixou para relatar as perseguições a que foi submetido em seu livro autobiográfico, suas memórias, reservando-se o papel de vítima nessa história. Corazza, de fato, optou por vitimizar-se, foi essa sua estratégia em relação à Pattarello.

Como visto anteriormente, eles se encontraram anos depois e no encontro Pattarello teria chorado ao ser lembrado - inclusive com um documento escrito - sobre suas maldades. É impossível, a princípio, saber se o choro de Pattarello foi de arrependimento ou não. Corazza, extremamente ressentido por Pattarello, não se adiantou em perdoá-lo. A partir das reflexões de Paul Ricouer, compreendeu-se o último encontro entre Corazza e Pattarello: do encontro emergiu uma certeza já esboçada por Ricouer: o perdão na história é realmente difícil.

Como é também difícil historicizar determinados processos históricos quando há escassez de certos tipos de fontes, no caso em tela, fontes que explorassem a missão orionita e o comportamento de seus membros por um ângulo interno: o dos bastidores da missão, objetivo deste estudo. Por esse motivo, essa foi a maior dificuldade encontrada para a construção deste estudo. Ou seja, a única fonte escrita sobre os missionários orionitas que revela os feitos desses religiosos na perspectiva privada é o registro de memória de Corazza.

Daí o fato de ter-se utilizado o registro de memória de Corazza, seu livro autobiográfico, como fonte exclusiva deste estudo. Ao optar-se por esse caminho, transformou-se as memórias de Corazza em documento, procedimento necessário como alertou Michel de Certeau, quando, na operação historiográfica, defendeu a necessidade de "separar, reunir, transformar em documentos certos objetos distribuídos de outra maneira" (CERTEAU, i982, p. 8I). "Certos objetos distribuídos de outra maneira" foi o que buscou-se empreender neste estudo, dar encadeamento e sentido a essas narrativas de Corazza, transformando-as em documentos para análise histórica. 


\section{C) HististóricA}

Evidentemente que os registros de memória de Corazza não são as únicas fontes possíveis sobre os orionitas. Mas insiste-se inferir que sobre os bastidores da missão, são sem sombra de dúvidas, a única fonte. Outros registros e fontes sobre os orionitas existem, mas sob a perspectiva que se privilegiou neste estudo, não. Importante destacar que durante a feitura deste, com a exceção de Corazza, todos os outros missionários citados não estavam mais vivos, o que inviabilizou qualquer possibilidade de coleta de depoimento oral. Para além dessa dificuldade, o próprio Corazza, já quase centenário, refugia-se na principal igreja orionita em Araguaína, cadeirante, doente e incomunicável.

Finalmente, sabe-se, portanto, a partir dos relatos de memória de Corazza e sob a ótica desse último, os bastidores da missão orionita à época. Mas qual representação teve sobre esses mesmos acontecimentos os outros personagens envolvidos nessa história, mas que não foram objetos deste estudo? Como observa-se, outras abordagens podem ajudar a entender a missão orionita na região. Este estudo a partir dos relatos de Corazza, é apenas um dentre outras leituras ainda possíveis sobre esses personagens e seus feitos.

\section{Referências}

ANSART, Pierre. História e memória dos ressentimentos. In: BRESCIANI, Stella \& NAXARA, Márcia. Memória e Ressentimento: Indagações sobre uma questão sensível. Campinas: Editora da UNICAMP, 2004.

AZZI, Riolando. A Neocristandade: Um Projeto Restaurador. Coleção História do Pensamento Católico no Brasil - V. São Paulo, Editora Paulus, 1994.

BENJAMIN, Walter. O narrador: considerações sobre a obra de Nikolai Leskov. In: _. Magia e técnica, arte e política: ensaios sobre literatura e história da cultura. $2^{\text {a }}$. São Paulo: Brasiliense, I985. P. 197-22I.

BOSI, Ecléa. O tempo vivo da memória: ensaios de psicologia social. São Paulo: Ateliê, 2003.

Memória e Sociedade: Lembranças de Velhos. $3^{\text {a }}$ ed. São Paulo, Companhia das Letras, 1994.

CAIXETA, Vera Lúcia. Médicos, Frades e Intelectuais: Leituras Sobre os Sertões do Brasil Central (I882-I935). Curitiba, Editora CRV, 20I4, p.89.

CERTEAU, Michel de. A escrita da história. Rio de Janeiro, Forense Universitária, 1982.

CORAZZA, Remígio. Silêncio Prudente. Fortaleza: Expressão, 2000.

FERRO, Marc. O Ressentimento na História. Ensaio. Agir Editora: Rio de Janeiro, 2009. 


\section{G) CitșTórica}

FOLI, Teresinha de Jesus Nóbrega. Meandros da Verdade. Fortaleza: GM, 2003.

FOUCAULT, Michel. A Escrita de Si. IN: Ética, Sexualidade e Política. Rio de Janeiro: Forense Universitária, 1983.

GAY, Peter. O Traço Comum, In: O Coração Desvelado: a experiência burguesa da Rainha Vitória à Freud. São Paulo: Cia das Letras, 1999, pp.337-376.

KONSTAN, David. Ressentimento - História de uma Emoção. In: BRESCIANI, Stella \& NAXARA, Márcia. Memória e Ressentimento: Indagações sobre uma questão sensível. Campinas: Editora da UNICAMP, 2004, p. 59-8I.

PATTARELlO, Giovanni. Perfil de Dom Orione. São Paulo: S/Editora, 1985.

PEREIRA, Lígia Maria Leite. Algumas Reflexões Sobre Histórias de Vida, Biografias e Autobiografias. História Oral. Mariana: FAFICH/UFMG, 2000.

RICOEUR, Paul. A Memória, A História, O Esquecimento. Campinas: Editora da Unicamp, 2007.

RODRIGUES, Jean Carlos. Espaço e Religião: A Presença da Congregação da Pequena Obra da Divina Providência no Antigo Norte Goiano (I950-1970). Revista Escritas, Vol.8, N.I, pp.4254, 2016.

SILVA, Raylinn Barros da. O Catolicismo Orionita no Antigo Extremo Norte Goiano nos Relatos de Memória dos "Filhos da Divina Providência" 1952-1980. Dissertação de Mestrado. Programa de Pós-Graduação em História. Goiânia: UFG, 2017.

Amor e paixão nos bastidores de uma missão religiosa católica no sertão do extremo norte de Goiás (atual norte tocantinense): Quinto Tonini e Teresinha Foli em seus relatos de memória. Albuquerque: Revista de História. Vol.ı, № 19 . Janeiro a julho de 20I8, p.I95-220.

TODOROV, Tzvetan. O homem desenraizado. Rio de Janeiro: Record, I999.

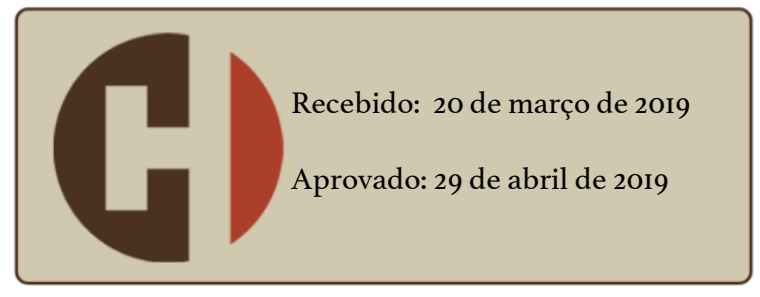

